\title{
KONSEP DAN NILAI BUDAYA JAWA DALAM \\ NOVEL JALAN MENIKUNG KARYA UMAR KAYAM
}

\section{THE CONCEPT AND CULTURAL VALUE OF JAVA IN \\ NOVEL JALAN MENIKUNG BY UMAR KAYAM}

\author{
Uman Rejo \\ STKIP Bina Insan Mandiri \\ Jalan Raya Menganti Kramat No. 133 Wiyung Surabaya \\ Pos-el: umanrejo@yahoo.com
}

\begin{abstract}
Abstrak
Karya sastra diciptakan untuk dinikmati, dipahami, dan dimanfaatkan oleh masyarakat. Perkembangan karya sastra selalu dikaitkan dengan manusia dan kehidupannya. Tulisan ini bertujuan untuk mendeskripsikan konsep-konsep budaya Jawa dalam novel Jalan Menikung karya Umar Kayam dan hubungan realita dalam masyarakat dengan kehidupan dalam novel Jalan Menikung. Metode yang dipergunakan adalah metode deskriptif analisis. Metode ini digunakan untuk menguraikan dengan memberikan pemahaman dan penjelasan yang memadai sehubungan dengan fakta-fakta empirik yang berkait dengan masalah yang diajukan dalam tulisan ini. Beberapa konsep budaya Jawa dalam novel ini di antaranya sikap feodalistik, sikap keagamaan, kerumangsan, aja dumeh yang dimiliki orang Jawa, sikap tepa slira dan mawas diri, serta hubungannya dengan sanak digambarkan secara gamblang dan jelas oleh Umar Kayam melalui watak dan cakapan masing-masing para tokoh di dalamnya. Hal itu merupakan bentuk pengejawantahan kehidupan Umar Kayam yang memang kental dengan aspek-aspek budaya Jawa, sehingga ia tahu betul bagaimana kehidupan orang Jawa, filsafat yang dianutnya memang sudah mendasar dalam dirinya. Filsafat tersebut difungsikan sebagai pedoman hidup, kunci pengendalian diri, dan sebagai pondasi dalam berinteraksi sosial.
\end{abstract}

Kata kunci: budaya Jawa, realita, orang Jawa, Jalan Menikung, Umar Kayam

\begin{abstract}
Literary works are created to be enjoyed, understood, and utilized by society. The development of literary works has always been associated with humans and their lives. This paper aims to describe the concepts of Javanese culture in the novel of Jalan Menikung by Umar Kayam and the relationship of reality in society with life in the novel of Jalan Menikung. The method used is descriptive method of analysis. This method is used to describe by providing sufficient understanding and explanation with respect to empirical facts relating to the problems proposed in this paper. Some of the concepts of Javanese culture in this novel include feudalistic attitudes, religious attitudes, kerumangsan, aja dumeh owned by the Javanese, the attitude of tepa slira and introspection, as well as its relation to the relatives depicted clearly and vividly by Umar Kayam through the character and conversation of each Figures in it. It is a form of embodiment of Umar Kayam's life which is thick with aspects of Javanese culture, so he knows very well how the life of the Javanese, his philosophy is already fundamental in him. Philosophy is functioned as a guide of life, the key to self-control, and as a foundation in social interaction.
\end{abstract}

Keywords: Javanese culture, reality, Javanese, Jalan Menikung, Umar Kayam

1. Pendahuluan

Karya sastra diciptakan untuk dinikmati, dengan manusia dan kehidupannya. Hasil dipahami, dan dimanfaatkan oleh masyarakat. karya sastra dapat pula dikatakan selalu 
berdampingan dengan lembaga sosial tertentu dalam masyarakat, karena sastra tidak dapat dilepaskan dari kehidupan dalam masyarakat. Seorang pengarang sebagai pencipta karya sastra juga merupakan anggota masyarakat.

Salah satu bentuk karya sastra adalah novel. Novel sebagai salah satu jenis karya sastra memuat nilai-nilai yang mengandung persoalan dengan bersumber dari kehidupan manusia, karena novel mengemukakan gagasan yang mewakili kondisi sosial dan waktu tertentu sehingga bukan semata-mata persoalan imajinasi yang lepas dari persoalan kehidupan. Sastra lahir ditengah-tengah masyarakat sehingga pada akhirnya sastra tetap melibatkan diri dalam masyarakat. Usaha sastra inilah turut membantu memberikan kontribusi bagi terbentuknya tata nilai kehidupan. Pembentukan tata nilai kehidupan inilah yang menambah nilai kearifan dan kebijaksanaan bagi seseorang.

Selain itu, dapat dikatakan bahwa karya sastra selalu berisi cerminan kehidupan yang sebenarnya dalam bentuk realita imajiner. Hal ini berarti kenyataan yang dialami seorang sastrawan dalam masyarakat ditangkap sebagai sebuah ide bagi karya sastra. Pernyataanpernyataan tersebut, sesuai dengan konsepkonsep yang tertuang dalam paradigma mimetik yang ditawarkan Abrams melalui buku The Mirror and The Lamp: Romantic Theory and The Critical Tradition (1958). Atmazaki (1990) mengemukakan antara mimesis dan kreatifitas yang melahirkan unsur fiksionalitas dalam karya sastra tidak dapat dipisahkan, karena kenyataan yang ada sebelum dituangkan dalam sebuah karya sastra selalu melewati proses kreatif dari seorang penulis.

Salah satu keunggulan yang dimiliki Umar Kayam dalam menulis novel Jalan Menikung adalah sikapnya yang konsisten dalam menggarap aspek sosial-budaya. engan komitmennya itu, orang yang membaca novel karya Umar Kayam dengan serta merta menjadi tercenung dan merasa langsung terlibat secara emosional. Apa yang diungkapkan dalam karyanya dirasakan pembaca menjadi bagian dari perhatiannya selama ini. Menurut Wellek dan Warren (1989) sebagai pengkaji atau peneliti karya sastra, gejala-gejala sosial-budaya seperti itu bukanlah fakta objektif, melainkan merupakan sikap mental yang kompleks dan hanya melalui karya sastralah paling jelas untuk menampilkannya.

Umar Kayam sebagai seorang sastrawan yang hidup dengan latar belakang masyarakat Jawa tentu yang dipahami dan dihayati adalah budaya Jawa. Jika diperhatikan dalam karyakarya yang pernah dihasilkannya, maka akan terlihat dengan jelas gaya penulisan dan ciri khas kepengarangannya. Dengan membaca sebuah karya sastra kita dapat mengambil nilainilai kehidupan yang ada dalam karya sastra tersebut, karena karya sastra sebagai cermin yang memantulkan bayangan semua bentuk manusia, baik fisik maupun psikis.

Sebagai cerminan kehidupan masyarakat, novel yang berjudul Jalan Menikung karya Umar Kayam ini merupakan salah satu dari karya sastra yang menceritakan kondisi suatu masyarakat beserta kompleks permasalahannya yang kental dengan nilai budaya Jawanya. Dalam novel ini, semua dinamika kehidupan sangat terasa seperti potret dari sebuah situasi sosial negara Indonesia pada saat ini. Kelebihan lain novel Jalan Menikung ini yakni jalan ceritanya tentang orang yang dilahirkan dalam masyarakat Jawa yang mengenal budaya Jawa sejak kecil, namun setelah dewasa dan hidup di luar negeri, mengenal budaya luar negeri, tetapi tetap merindukan budaya negeri sendiri, yaitu budaya Jawa.

Alasan lain dipilihnya nilai budaya Jawa dalam novel Jalan Menikung karya Umar Kayam, karena di dalam novel ini banyak mengajarkan falsafah hidup dan nilai-nilai moral yang tinggi. Berangkat dari permasalahan tersebut, pendekatan yang digunakan dalam mengkaji novel ini adalah pendekatan mimetik. Karena dalam pendekatan mimetik bertolak dari kenyataan, bahwa tidak semua karya sastra itu fiksi. Tetapi kadang kala ada dalam realita atau kenyataan, begitu juga yang ada dalam novel Jalan Menikung karya Umar Kayam.

Rumusan masalah yang digunakan adalah bagaimana konsep dan nilai budaya Jawa dalam novel Jalan Menikung karya Umar 
Kayam; dan bagaimana hubungan realita yang ada dalam masyarakat dengan kehidupan pada novel Jalan Menikung karya Umar Kayam. Tulisan ini bertujuan untuk mendeskripsikan konsep budaya Jawa dalam novel Jalan Menikung karya Umar Kayam, dan mendeskripsikan hubungan realita yang ada dalam masyarakat dengan kehidupan pada novel Jalan Menikung karya Umar Kayam.

\section{Teori dan Metode}

\subsection{Landasan Teori}

\subsubsection{Pendekatan Mimetik}

Dalam menelaah sebuah karya sastra kita dapat menggunakan berbagai pendekatan dalam sastra, seperti yang diungkapkan Abrams (1958) bahwa pendekatan dalam mengkaji karya sastra itu ada empat macam, yaitu (1) pendekatan mimetik yang memandang karya sastra sebagai tiruan atau pembayangan kehidupan dunia nyata; (2) pendekatan pragmatik memandang makna karya sastra ditentukan oleh publik pembaca selaku penyambut karya sastra; (3) pendekatan ekspresif yang memandang karya sastra sebagai pernyataan dunia batin pengarang yang bersangkutan; dan (4) pendekatan objektif yang memandang karya sastra sebagai dunia otonom yang dapat dilepaskan dari siapa pengarang dan lingkungan sosial-budaya zamannya, sehingga karya sastra dapat dianalisis berdasarkan strukturnya. Bertolak dari berbagai pendekatan yang ditawarkan oleh Abrams di depan, maka pendekatan yang diambil dalam tulisan ini adalah pendekatan mimetik, yaitu pendekatan yang bertolak dari pemikiran tentang sebuah karya sastra sebagai hasil seni yang merupakan representasi kehidupan nyata, serta merupakan paduan antara kenyataan dengan imajinasi pengarang yang berpijak pada kenyataan itu sendiri.

Hubungan antara karya sastra dengan kenyataan dalam suatu realita telah menjadi pembicaraan sejak zaman Yunani Kuno. Pembicaraan tentang hubungan karya sastra dengan realitas tersebut telah diawali oleh dua tokoh bangsa Yunani, yaitu Plato (428-348 SM) dan Aristoteles (348-422 SM) (Damono, 2009). Pandangan-pandangan Plato tentang teori sastra termuat dalam buku Republika.
Plato berpandangan bahwa kebenaran tertinggi hanya ada pada dunia ide atau Ilahi. Karya seni menurut Plato tidak dapat mencapai dunia tersebut. Karya seni hanyalah tiruan atau mimesis dari kenyataan yang ada di dunia nyata. Karena sifatnya hanya meniru, karya seni tentu tidak sama persis dengan yang ditiru. Seorang tukang lebih dihargai karena menghasilkan barang secara persis daripada seorang seniman. Kenyataan sehari-hari yang ditiru seorang seniman pun sebenarnya adalah tiruan dari dunia ide atau Ilahi.

Pandangan Plato itu mendapat sanggahan dari muridnya sendiri, yaitu Aristoteles. Aristoteles memandang bahwa karya sastra tidak hanya sekadar tiruan dari kenyataan sehari-hari (Teeuw, 1988). Karya sastra memang bertolak dari kenyataan, tetapi kenyataan yang diciiptakan oleh seniman adalah kenyataan yang baru, yang merupakan hasil olahan daya kreativitas seniman terhadap kenyataan. Selanjutnya Aristoteles (Damono, 2009) menjelaskan bahwa karya seni atau sastra justru dapat menyucikan jiwa manusia lewat proses katharsis. Dengan membaca karya sastra, manusia dibebaskan dari nafsu rendah dan mempertinggi jiwa sastra budi manusia. Jadi, menurut Aristoteles kedudukan seniman lebih tinggi daripada seorang tukang. Seniman mengandalkan kepandaiannya untuk menafsirkan kenyataan yang ada di sekitarnya.

Berdasarkan pendapat Aristoteles (Damono, 2009) disimpulkan bahwa seniman lebih tinggi nilai karya seninya daripada seorang tukang. Sebab oleh seniman, penafsiran terhadap kenyataan yang dominan dan kepandaiannya dalam hal ini diabdikan dalam interpretasi sebagai proses pemberian makna eksistensi manusia. Karya seni menurut Aristoteles menjadi sarana pengetahuan yang khas, sebagai cara yang unik untuk membayangkan pemahaman tentang situasi manusia yang dapat diungkapkan dan dikomunikasikan dengan jalan yang lain. Kenyataan dalam masyarakat yang digambarkan lewat sastra pada hakikatnya merupakan lukisan yang dipadukan dengan imajinasi yang memberikan kemungkinan munculnya nilai-nilai estetis. Karya sastra bukan hanya pemindahan kenyataan yang ada 
dalam hidup yang sebenarnya melainkan juga menampilkan sikap pengarang terhadap kenyataan berdasarkan observasinya, pengalamannya, dan imajinasinya.

Bertolak dari keterangan di depan, dapat disimpulkan bahwa antara karya sastra dan kenyataan tidak dapat dipisahkan. Sastra merupakan tiruan atau perpaduan antara kenyataan dengan imajinasi pengarang yang berpijak dari kenyataan. Oleh karena itu muncullah kritik sastra mimetik, yakni kritik sastra yang melihat hubungan karya sastra dengan realitas untuk mengetahui seberapa jauh karya sastra menggambarkan masyarakat.

\subsubsection{Konsep Budaya Jawa}

Kehidupan masyarakat Jawa, terutama yang berkaitan dengan pola masyarakat, banyak dijumpai hal-hal yang unik sehubungan dengan tradisi atau pemikirannya. Masyarakat Jawa adalah masyarakat yang mendambakan kedamaian dan ketentraman mereka berusaha menempatkan diri sesuai dengan posisinya dalam lingkungan masyarakat.

Menurut Hardowirogo (1995) ada beberapa ciri khas manusia Jawa yaitu: (1) sifat feodalistik manusia Jawa yaitu manusia Jawa begitu kuat terikat oleh tradisi dan tata gaul feodalistik sehingga ia belum bisa bersikap dan berbicara bebas di dalam masyarakat; (2) sikap keagamaan manusia Jawa yaitu sehubungan dengan agama yang dianutnya, sikap keagamaan manusia Jawa boleh dikatakan nominal, dalam arti bahwa ia tidak saleh sepenuhnya terkecuali orang yang memang benar-benar beriman; (3) manusia Jawa rumangsan artinya perasa bahwa tindak tanduknya selalu diperhatikan orang, sehingga takut berbuat ssesuatu yang melanggar tata susila dan kesopanan; (4) manusia Jawa dan aja dumeh yaitu suatu keadaan kejiawaan yang mendorong seseorang untuk bersikap serta berbuat tertentu selagi dia berkuasa hingga dapat menampakkan diri berupa kekuasaan; (5) manusia Jawa dan tepa slira yaitu berusaha menempatkan diri dalam keadaan orang lain, sehingga dapat mengerti mengapa orang lain itu dalam hubungan dengan keadaannya sampai dapat melakukan perbuatan itu; (6) manusia Jawa dan mawas diri yaitu meninjau ke dalam ke hati nurani guna mengetahui benar tidaknya, bertanggung jawab tidaknya suatu tindakan yang telah diambil; dan (7) manusia Jawa dan sanak. Orang Jawa pada umumnya suka pada sanak. Di manapun ia berada, ia kelihatan senang bila bertemu dengan seorang sanak.

Menurut Suseno (1993) dalam etika Jawa ada dua kaidah dasar kehidupan manusia Jawa, yaitu dalam setiap situasi manusia hendaknya bersikap sedemikian rupa hingga tidak sampai menimbulkan konflik ini disebut prinsip kerukunan dan agar manusia dalam cara berbicara dan membawa diri selalu menunjukkan sikap hormat terhadap orang lain, sesuai dengan derajat dan kedudukannya, ini disebut dengan prinsip hormat.Dalam kehidupan orang Jawa, baik pergaulan maupun tradisi budaya selalu terlihat pengungkapan nilai-nilai filsafat Jawa yang mempengaruhi semua tindak dan perilakunya. Sikap hidup ini mau tidak mau seakan-akan melekat erat dalam konsep pemikiran orang Jawa, walaupun ada satu dua diantaranya yang mengabaikan hal itu.

Karya sastra yang besar bukanlah karya yang hanya menyodorkan hiburan belaka, melainkan yang juga mendorong pembacanya untuk berpikir dan menilai karya sastra tersebut. Sehingga tidak berlebihanlah bila dikatakan karya sastra yang besar kuat daya khayal pengarangnya adalah sebuah penafsiran kembali dari persoalan-persoalan masyarakat, termasuk sejarah dan pengalaman sosial manusia dalam lingkungan dan zamannya. Oleh karena itu, karya sastra terutama novel pada umumnya lebih peka terhadap persoalanpersoalan sosial suuatu masyarakat pada suatu masa tertentu bila dibanding dengan jenis karya sastra yang lain, sebab ada keleluasaan untuk menguraikan dan menafsirkan bahasa dan kata melalui adegan, situasi, dan tokohtokoh yang bermacam-macam watak dan latar belakangnya.

\subsection{Metode}

Kajian sastra ini menggunakan pen-dekatan sosiologi sastra. Menurut Ratna (2004), pendekatan sosiologi sastra dapat membantu memahami konsep dan nilai budaya Jawa dalam novel ini. Pendekatan sosiologi sastra 
memosisikan analisis manusia sebagai bagian dari masyarakat, dengan proses pemahaman yang dimulai dari masyarakat ke individu. Pendekatan ini beranggapan karya sastra sebagai milik masyarakat. Pendekatan sosiologi sastra digunakan karena memiliki implikasi metodologis yang berupa pemahaman dasar berkenaan dengan kehidupan yang terjadi di masyarakat. Pendekatan ini juga mempunyai keterkaitan hubungan antara karya sastra dengan masyarakat. Selain itu, pendekatan ini juga digunakan untuk membantu memahami berkenaan dengan konsep dan nilai budaya Jawa.

Kajian ini termasuk dalam penelitian kepustakaan (library research). Objek materialnya adalah novel Jalan Menikung karya Umar Kayam. Adapun objek formalnya adalah konsep dan nilai budaya Jawa yang terkandung dalam novel ini.

Sumber data yang digunakan ada dua, yaitu sumber data primer dan sekunder. Sumber data primer atau objek yang dipakai adalah novel Jalan Menikung karya Umar Kayam. Sumber data penunjang atau sekunder (pendukung) yang dipakai adalah buku-buku tentang konsep dan nilai budaya Jawa. Selain buku-buku tersebut, data penunjang yang dipakai juga berupa esai, makalah, dan karya ilmiah (yang berupa skripsi, tesis, dan disertasi). Data yang dipakai adalah kata-kata yang terdapat dalam novel Jalan Menikung karya Umar Kayam.

Teknik pengumpulan data yang digunakan adalah teknik pustaka dan teknik catat. Teknik pustaka dapat diartikan pemerolehan data dengan mengamati sumber tertulis. Data yang berupa kutipan kata-kata, kalimat, dan wacana tersebut dibaca kemudian dicatat beberapa hal yang sesuai dengan aspek permasalahan dalam kajian ini. Data-data itu selanjutnya disalin dalam korpus data.

Teknik analisis data yang digunakan adalah teknik analisis isi atau content analysis. Teknik analisis isi digunakan untuk mengungkap, memahami, dan menangkap pesan yang terkandung dalam karya sastra dan pemahaman tersebut membutuhkan interpretasi sastra. Ratna (2004) menyatakan analisis isi selalu berhubungan dengan isi komunikasi. Dalam karya sastra, isi yang dimaksud adalah pesan-pesan. Sebagaimana metode kualitatif, dasar pelaksanaan metode analisis adalah penafsiran atau interpretasi. Dasar penafsiran inilah yang memberikan perhatian lebih pada isi pesan.

\section{Hasil dan Pembahasan \\ 3.1. Sikap Feodalistik Orang Jawa}

Mengenai sikap feodalistik orang Jawa dalam novel Jalan Menikung karya Umar Kayam dapat dilihat dari dua hal, yakni sikap orang Jawa dalam perjodohan dan sikap orang Jawa dalam pergaulan. Masyarakat Jawa begitu kuat terikat oleh tradisi dan tata gaul feodalistik, sehingga ia belum bisa bersikap dan berfikir terbuka. Sebagai anak, Harimurti sangat menghormati sikap kedua orang tuanya yang ingin menjodohkan dia dengan saudara dekat dari ibunya. Dia tidak bisa menolak kehendak kedua orang tuanya. Perhatikan data berikut ini.

"Nuwun sewu pangak sama, mohon seribu
maaf, bapak dan ibu. Sekali-sekali bukan
maksud saya untuk melecehkan rencana bapak
dan ibu untuk menjodohkan saya dengan Suli.
Sejak semula saya memang sudah akan
menyerah kepada rencana bapak dan ibu,
karena saya tahu sepenuhnya bapak dan ibu
hanya menginginkan yang terbaik buat saya"
(Kayam, 1999:6).

Tommi tidak setuju bermantukan seorang keturunan Tionghoa, benar-benar tidak mau menghadiri pernikahan anaknya yang paling bungsu yaitu Anna dengan Boy Saputra yang berlangsung di rumah besannya di Semarang. Tommi sangat membanggakan keturunan. Ia tidak mau kepriyayian darah anak cucunya dicampuri darah Cina. Hal ini terlihat dalam data berikut.

"Kalian tahu, saudara-saudaraku, nama Handoyo itu sebenarnya? Han Swie Kun! Coba, adik-adikku, darah Sastrodarsono mau dicampur dengan darah Han Swie Kun.apa tidak kacau nanti” (Kayam, 1999:78).

Dalam masyarakat Jawa memang berlaku prinsip pemilihan jodoh yang didasarkan pada bobot, bibit, dan bebet. Bobot dapat diartikan bahwa pemilihan jodoh itu di dasarkan pada 
berat atau isi kekayaannya. Bibit diartikan pemilihan jodoh itu didasarkan pada benih yang baik, sedangkan bebet diartikan sebagai keturunan.

Dalam tata pergaulan, orang Jawa selalu menghormati orang yang lebih tua. Apabila melalui ruangan yang penuh sesak, di mana kebetulan bukan atasannya, orang Jawa tidak berani berjalan biasa, otomatis dia akan membungkuk hormat. Di hadapan atasan tidak pernah seorang bawahan yang berasal ari jawa mengatakan tidak dan sellalu menyatakan penolakkannya secara halus dengan senyum di bibir dengan maksud supaya tidak mengecewakan dan menyakiti hati orang yang tawaran dan permintaannya ditolak. Harimurti diajak Maryanto makan siang direstoran Phoenik. Dia sangat heran mengapa Maryanto yang menjadi pemimpin redaksi di kantor penerbitan Mulia Mutu yang bergengsi mengajak staf redaksi rendahan seperti Harimurti. Harimurti tidak bisa menolak perminataan bosnya itu, karena dia berusaha membuat senang bosnya. Pada masyarakat kita, di mana usaha membuat senang atasan tentu banyak dilakukan bawahan manapun terhadap atasannya.

\subsection{Sikap Keagamaan Orang Jawa}

Orang Jawa selalu menghormati dan mendoakan para leluhurnya yang sudah meninggal. Tommi mengadakan proyek pemugaran makam kakeknya, Eyang Sastrodarsono, dan makam orang tuanya di Wanawalas, Madiun Jawa Timur. Makam serta nisan leluhur mereka yang semula berupa perkuburan sederhana diganti dengan bahan marmer buatan Italia. Pada malam menjelang peresmiannya, Tommi mengundang para santri dari kampung sekitar untuk membaca Alquran pada malam hari di kompleks makam

Kebiasaan mendoakan orang tua yang sudah meninggal di makam dalam kehidupan nyata sudah menjadi tradisi orang Jawa. Setiap ada hari besar keagamaan orang Jawa selalu berkunjung ke makam keluarganya dengan membawa kembang boreh. Tradisi ini turun menurun sampai sekarang.

\subsection{Orang Jawa Rumangsan}

Masyarakat Jawa sangat perasa bahwa tindaktanduknya selalu diperhatikan hingga takut untuk berbuat sesuatu yang melanggar tata susila dan kesopanan. Kepekaan orang Jawa akan gunjingan, kadang-kadang memang keterlaluan. Ia menjadi manusia yang takut untuk melakukan sesuatu secara terbuka, oleh karena kesaksian orang lain dianggap bisa menjadi sumber omongan yang bikin malu dirinya. Karena ia wedi isin (takut malu), ia pun berusaha menjauhkan diri dari segala perbuatan yang bisa mengakibatkan rasa malu itu.

Dirjen sebuah instansi pemerintah itu adalah rekan kerja Tommi. Beliau sering melakukan kolusi dengan Tommi dan itu diketahui oleh sekretarisnya yaitu Endang Prameswari, karena Endang sering disuruh mengubah angka-angka sebenarnya dari biaya proyek mereka. Waktu Tommi mengajak makan siang Dirjen itu menolak dengan alasan takut dilihat karena dia seorang Dirjen kok makan siang dengan rekanan. Hal ini dapat diperhatikan dalam data berikut.

"Boleh kalau mau ajak Endang. Asal jangan lama-lama. Saya sendiri jangan! Apa kata orang nanti, Dirjen makan siang dengan rekanan" (Kayam, 1999:54).

Corak watak umum warga masyarakat yang dalam kenyataannya sedikit banyak memang selalu merasa diawasi dalam segala perbuatannya. Apalagi kalau sudah menjadi orang pangkat dia akan malu kalau berjalan dengan orang biasa. Ia merasa tindakannya itu akan merendahkan kedudukan dan martabatnya.

Perkembangan kejiwaan di dalam masyarakat Jawa dewasa ini sudah sedemikian majunya hingga orang Jawa sekarang boleh dikatakan sudah bebas dari rasa takut berbuat di dalam masyarakat karena itu orang umumnya sudah bisa sampai pada anggapan bahwa setiap perbuatan baik atau buruk selalu menjadi bahan pembicaraan orang. Dia menjadi rakus akan materi, menjadi kebal akan rasa takut malu dan bahkan berkembang lebih lanjut menjadi tak kenal malu lagi. Perhatikan data berikut. 
"Yaa, kok cuma seratus juta. Kok pelit juga konglomerat ini. Ah, nggak apa. Sumbangan untuk perindahan kota saya jadikan proyek pribadi saja. Lumayan, dua kali seratus juta [...]" (Kayam, 1999:145).

Sebelum tiba hari peresmian pemugaran kompleks pemakaman Eyang Sastrodarsono, Tommi memberikan uang kaget kepada Pak Bupati Wanagalih, Tommi menginginkan uang itu dianggap sebagai sumbangan pengembangan kota. Namun kenyataannya uang itu dipakai untuk kepentingan pribadi. Dalam kehidupan nyata ini adalah cermin materialisme orang Indonesia yang mengejar harta kekayaan hanya sebagai tujuan hidup. Perilaku salah kaprah orang Indonesia yang membiasakan suap-menyuap dan orang tak lagi berusaha untuk hanya secara halal menjadi kaya, orang tak segan-segan lagi untuk mencari kekayaan dengan cara batil.

Dalam kehidupan nyata ini merupakan cermin materialisme orang Indonesia yang mengejar harta kekayaan hanya sebagai tujuan hidup. Perilaku salah kaprah orang Indonesia yang membiasakan suap menyuap dan orang tidak lagi berusaha untuk hanya secara halal menjadi kaya, orang tidak segan-segan lagi untuk mencari kekayaan dengan cara yang detil.

\subsection{Orang Jawa dan Aja Dumeh}

Sikap hidup orang Jawa yang etis dan taat pada adat warisan nenek moyang serta selalu mengutamakan kepentingan umum atau masyarakat dibanding dengan kepentingan pribadi secara jelas tergambar dalam pedoman hidup aja dumeh ini. Aja dumeh adalah pedoman mawas diri bagi semua orang Jawa yang sedang dikarunia kebahagiaan hidup oleh Yang Maha Esa. Aja dumeh adalah suatu peringatan agar seseorang selalu ingat kepada sesamanya. Hal ini dapat diperhatikan dalam data berikut.

"Ternyata keadaan keturunan beliau-beliau ini secara ekonomis sangat mundur. Mereka tidak pernah mampu memelihara makammakam keluarga-nya, apalagi memugarnya. Jadi, kita ulurkan tangan kami sebagai tanda simpati keluarga kita dengan mereka" (Kayam, 1999:46).
Masyarakat Jawa gemar mengintropeksi diri mengenai kekurangan-kekuranganya sebagai makhluk di dunia ini. Dengan menyakini sikap aja dumeh ini, orang Jawa tidak akan berbuat semena-mena kepada sesamanya, baik dalam hal kekuasaan atau dalam hal kekayaan. Aja dumeh ini sekaligus juga merupakan sikap pengendalian diri karena pada dasarnya masyarakat Jawa tidak pernah terlepas dari rasa kebersamaan dan saling memilki antara yang satu dengan yang lainnya. Karena pada hakikatnya kebahagiaan seseorang itu tidak mungkin dicapai dengan bekerja sendiri, tetapi atas bantuan temanteman serta masyarakat disekelilingnya.

Untuk pedoman mawas diri (aja dumeh) ini saya megikuti pedoman yang ditawarkan oleh Herusatoto (2000) yang berbunyi sebagai berikut: (1) aja dumeh kuasa, tumindake daksura lan daksia marang sapada-pada (jangan mentang-mentang berkuasa, sehingga tindak-tanduknya pongah, congkak serta sewenang-wenang terhadap sesamanya); (2) aja dumeh pinter tumindake keblinger (jangan mentang-mentang pintar, kebijakasanaannya menyimpang dari aturan-aturann seharusnay); (3) aja dumeh kuat lan gagah, tumindake sarwa gegabah (jangan mentang-mentang kuat dan gagah, lalu tindakannya selalu gegabah atau semaunya sendiri saja); (4) aja dumeh sugih, tumindake lali karo wong ringkih (jangan mentang-mentang kaya, lalu perbuatannya tidak mengingat mereka yang lemah ekonomi); dan (5) aja dumeh menang, tumindake sewenang-wenang (jangan mentang-mentang telah dapat mengalahkan lawan, lalu tindakkannya sewenang-wenang terhadap yang dikalahkan). Sikap hidup ini masih diyakini nilainya bagi orang Jawa yang mengharapkan kesempurnaan hidup dengan keluhuran hidup.

Namun, tindakan Tommi yang memindahkan kuburan mereka yang tidak ada hubungan darah atau pertalian darah tanpa musyawarah membuat Harimurti dan Lantip sangat marah. Tanpa mempedulikan sejarah hubungan emosional diantara orang tuanya dan para sahabatnya di masa lalu. Atas teguran Harimurti yang menyayangkan penggusuran makam-makam teman main kartu juga sudah 
diakui sebagai para sesepuh keluarga, dengan enaknya Tommi menjawab bahwa:

"pemindahan itu sudah dilakukan dan dilaksanakan dengan baik-baik [...] dengan ganti rugi yang pantas" (Kayam, 1999:45).

Itulah sebuah jawaban enteng yang datang dari kebenaran menurut ukuran sendiri dan menyangka segala sesuatu yang bisa diukur dengan uang.Penguasa zaman sekarang seenaknya menggusur rakyat kecil atau orang miskin dengan dalih untuk kepentingan orang banyak dan memberikan ganti rugi yang tidak seberapa. Dan pedoman mawas diri aja duweh kuoso sudah tidak dihiraukan lagi. Yang penting dia melaksanakan tugasnya meskipun rakyat kecil menderita akibat perbuatannya itu.

\subsection{Orang Jawa dan Tepa Slira}

Prinsip tepa slira berarti berusaha menempatkan diri dalam keadaan orang lain hingga dapat mengerti mengapa orang lain itu dalam hubungan dengan keadaan sampai dapat melakukan perbuatan tertentu. Orang yang memiliki prinsip ini berusaha untuk dapat lebih mengerti mengapa sampai terjadi suatu perbuatan dan tidak akan berbuat gegabah dengan bertindak tegas. Dia tidak mau cepatcepat menyalahkan orang karena ingin mengetahui terlebih dahulu motif-motif yang menyebabkan dilakukannya tindak pidana, misalnya. Memang dalam hal ini, kita lebih baik bersikap hati-hati daripada grusa-grusu, gegabah menyalahkan orang yang mungkin terdorong oleh keadaan terpaksa melakukan tindakan pidana. berikut.

Hal ini dapat diperhatikan dalam data

"Kesalahan yang pernah bapak lakukan dulu sekali, bahkan sebelum ada kamu, sekarang diungkit-ungkit lagi. Padahal bapak, dulu sekali, berkat pertolongan dan perlindungan almarhum Eyang Nugraha, sudah resmi dinyatakan bebas dan boleh kerja di mana saja asal bukan instansi pemerintah" (Kayam, 1999:24).

Harimurti dulu pernah melakukan kesalahan besar dengan menjadi anggota PKI yang dilarang di Indonesia. Namun dengan pertolongan Pak Dhenya yang bernama
Nugroho yang waktu itu menjadi tentara yang berpangkat kolonel, sehingga Harimurti bisa diterima diperusahaan penerbit Mulia Mutu. Namun sekarang kejadian itu diungkit-ungkit lagi. Harimurti dianggap bisa membahayakan pemerintah. Tindakan Maryanto yang memecat Harimurti dianggap tidak bersih diri dan keadaan dirinya dianggap bisa membahayakan pemerintah. Tindakan Maryanto yang memecat Harimurti tanpa mempertimbangkan terlebih dahulu keadaan dan masa depan Harimurti, membuktikan bahwa Maryanto kurang bertepa slira.

Dalam kehidupan nyata di masyarakat, kita sekarang banyak pabrik-pabrik yang memPHK karyawannya dengan seenaknya sehingga mereka kehilangan mata pencaharian dan masa depan. Padahal mereka belum tentu bersalah. Kita tidak boleh bertindak secara gegabah dengan menyalahkan orang yang belum tentu bersalah. Namun akhir-akhir ini tindakan main hakim sendiri dan pengeroyokkan masa sudah mewabah di mana-mana. Hal ini terjadi karena ada unsur kepentingan pihak-pihak tertentu yang menginginkan kehancuran itu terjadi.

\subsection{Orang Jawa dan Mawas Diri}

Mawas diri yaitu meninjau ke dalam hati nurani guna mengetahui benar tidaknya bertanggung jawab tidaknya suatu tindakan yang telah diambil. Manusia Jawa memang sering berbicara tentang mawas diri dan berusaha pula untuk mempraktikkannya guna mendapatkan jawaban atas persoalan yang dihadapinya, yakni apakah suatu perbuatan yang dilakukannya, suatu tindakan yang diambilnya secara moral dapat dibenarkan dan dipertanggungjawabkan. Hal ini dapat dilihat dengan memperhatikan data berikut.

"Aku kalian tahu, kami tidak bermaksud jelek. Sebaliknya kami mengambil inisiatif ini justru untuk menegakkan prinsip mikul duwur mendem jero" (Kayam, 1999:46).

Kalau mawas diri dulu hanya diibaratkan di dalam masyarakat Jawa, masyarakat Indonesia pun dewasa ini sering mengetengahkannya sebagai semacam pengecekkan batiniah mengenai benar tidaknya suatu tindakan yang diambil. Kejujuran terhadap hati nuranilah yang menjadi jaminan mawas diri. Kita sebagai manusia tidak boleh 
bersifat adigang, adigung, dan adiguna. Adigang adalah watak sombong, karena mengandalkan kekayaan dan pangkat. Adigung adalah watak sombong karena mengandalkan kepandaian dan kepintaran lantas meremehkan orang lain. Dan adiguna adalah watak sombong karena mengandalkan keberanian dan kepintaran yang bersilat lidah. Sebenarnya keberanian dan kepintaran yang bersilat lidah itu hanya umbar omongan atau besar mulut saja.

Sebagai anak pungut, Lantip berusaha untuk membantu keluarga yang memungutnya. Dia selalu berusaha membantu dan menyelesaikan masalah yang dihadapi adiknya. Eko meskipun sudah lama tinggal di Amerika, namun dia tidak kehilangan kepribadian Jawanya. Setiap ada waktu luang dia selalu memainkan siternya dan nembang perkutut manggung. Kalau sudah melantunkan tembang itu, Eko selalu teringat keluarganya di Jawa. Ayah dan ibunya juga seperti itu bila ada waktu senggang. Jadi meskipun Eko tinggal di Amerika tetapi perasaan dan tingkah lakunya masih seperti orang Jawa.

Lain halnya dengan keluarga Tommi dan Jeannete, dia selalu memamerkan kekayaannya dihadapan semua orang. Begitu juga dengan anaknya yang bernama Bambang. Tommi dan Jeannete meskipun dia orang Jawa dan tinggal di Jakarta tetapi gaya hidupnya ala barat. Rumahnya bergaya Spanyol, tetapi Marijan lebih suka makanan khas Jawa yaitu gudeg dan rujak cingur.

Kebanyakan masyarakat kita sekarang sudah kehilangan ajaran mawas diri seperti apa yang digambarkan dalam tokoh Tommi dan Jianette yang bergaya hidup mewah dan sombong. Padahal belum diketahui harta yang diperolehnya itu darimana. Dan kebanyakan masyarakat kita sekarang kalau sudah mempunyai kedudukan dan jabatan yang enak, maka ia akan lupa diri dan berusaha mempertahankan jabatannya dengan cara apapun.

\subsection{Orang Jawa dan Sanak}

Orang Jawa umumnya suka pada sanak. Di manapun ia kelihatan senang bila bertemu dengan seorang sanak. Dia tidak akan menyembunyikan rasa senang dan akan bercerita tentang hubungan kekeluargaan yang ada di antara dia dan orang yang baru saja ditemukan sebagai sanak. Mungkin hanya berkakek buyut sama. Dalam hal ini dua orang sanak adalah misanan satu sama lain. Bila dua orang itu berkakek atau bernenek sama, mereka adalah nak ndulur satu sama lain.

Waktu Eko dan Claire berkunjung ke Indonesia orang tuanya menyuruh Eko untuk sowan ke rumah $\mathrm{Bu}$ Dhe dan Pak Dhenya. Kunjungan pertama ke rumah Pak Dhe dan $\mathrm{Bu}$ Dhe Tommi. Di sana Eko di sambut dengan gembira. Meskipun Tommi dan Jiannete orang kaya, tetapi dia sangat senang dikunjungi Eko. Sewaktu pulang Eko diberi hadiah angpau berisi sepuluh ribu dolar oleh Pak Dhenya. Claire juga diberi hadiah oleh Jinette, berupa perhiasan berlian, dan Claire disuruh memilih sendiri perhiasan yang disukainya.

Kunjungan kedua Eko mendatangi rumah $\mathrm{Bu}$ Dhe dan Pak Dhe Marijan. Di sana Eko juga diterima dengan senang hati dan pulangnya Eko juga diberi angpau yang berisi lima ribu dolar. Kunjungan yang terakhir ke rumah Pak Dhe dan Bu Dhe Lantip, meskipun pulangnya tidak mendapat angpau, namun Eko dan Claire sangat terkesan dan sangat puas karena kehangatan dan kasih sayang yang tulus.Tommi meskipun sombong tetap suka pada sanaknya. Pada acara apapun Tommi berusaha untuk mengundang dan mengumpulkan keluarganya. Tommi sangat senang apabila keluarganya bisa berkumpul semua.

Dalam kehidupan nyata, masyarakat Jawa memang senang pada sanak. Ini terbukti di setiap keluarga ada yang namanya arisan keluarga atau pertemuan keluarga, yang harus diikuti oleh semua anggota keluarga. Dan ini biasanya diadakan setahun sekali atau bergantung kesepakatan bersama seluruh anggota keluarga.

\section{Simpulan}

Berdasarkan analisis di depan, maka bisa dikatakan bahwa novel yang ditulis oleh Umar Kayam ini memiliki beberapa kelebihan di dalamnya. Kelebihan yang dimaksud di antaranya sebagai berikut. Pertama, penyajian 
konsep daan nilai budaya Jawa dalam novel ini seperti sikap feodalisitik orang Jawa, sikap keagamaan orang Jawa, orang Jawa yang rumangsan, orang Jawa yang aja dumeh, orang Jawa yang tepa slira, orang Jawa yang mawas diri, orang Jawa dan sanak, itu semua digambarkan secara gamblang dan jelas oleh Umar Kayam melalui watak dan dialog masing-masing para tokohnya. Itu merupakan bentuk pengejawantahan kehidupan Umar Kayam yang memang kental dengan aspekaspek budaya Jawa sehingga ia tahu betul bagaimana kehidupan orang Jawa, filsafat yang dianutnya memang sudah mendasar dalam dirinya. Di dalam budaya Jawa terkandung filsafat Jawa yang berkembang dalam kehidupan masyarakat Jawa. Dan filsafat yang berkembang dalam masyarakat itu berfungsi sebagai pedoman hidup, kunci pengendalian diri, dan sebagai dasar dalam berinteraksi sosial.

Kedua, seluruh substansi dalam novel ini merupakan kelanjutan dari novel Para Priyayi, dua seri novel atau dwilogi dari pengarang yang sama. Kedua novel ini sama-sama mengungkapkan fenomena sosial-budaya yang sudah dan sedang berlangsung di Indonesia. Dalam novel ini berisi kutipan beberapa fenomena gaya hidup (life style) keturunan priyayi masa kini, sebagai hasil jerih payah penegak kepriyayian zaman dulu. Faktor zaman ternyata mampu mengubah esensi ideologi kepriyayian dari makna semula, bahkan bertolak belakang. Dan itu merupakan realita yang ada di masyarakat kontemporer seperti saat ini.

Salah satu keunggulan yang dimiliki Umar Kayam dalam menulis novelnya adalah sikapnya yang konsisten dalam menggarap aspek sosial-budaya. Dengan komitmennya itu, orang yang membaca novel-novel karya Umar Kayam dengan serta merta menjadi tercenung dan merasa langsung terlibat secara emosional. Apa yang diungkapkan dalam karyanya dirasakan pembaca menjadi bagian dari perhatiannya selama ini. Kelebihan novel Jalan Menikung ini yaitu jalan ceritanya tentang orang yang dilahirkan dalam masyarakat Jawa yang mengenal budaya Jawa sejak kecil, namun setelah dewasa dan hidup di luar negeri, mengenal budaya luar negeri, tetapi tetap merindukan budaya negeri sendiri, yaitu budaya Jawa.

\section{Daftar Pustaka}

Abrams, M.H. 1958. The Mirror and The Lamp: Romantic Theory and The Critical Tradition. New York: Oxford University Press.

Atmazaki. 1990. Ilmu Sastra: Teori dan Terapan. Padang: Angkasa.

Damono, Sapardi Djoko. 2009. Sosiologi Sastra: Pengantar Ringkas. Depok: Editum.

Hardowirogo, Marbangun. 1995. Manusia Jawa. Jakarta: Toko Gunung Agung.

Herusatoto, Budiono. 2000. Simbolisme dalam Budaya Jawa. Yogyakarta: Hanindita Graha Widia.

Kayam, Umar. 1999. Jalan Menikung. Jakarta: Grafiti.

Ratna, Nyoman Kutha. 2004. "Relevansi Teori-teori Postrukturalisme dalam Memahami Karya Sastra, Aspek-aspek Kebudayaan Kontemporer pada Umumnya". Pidato Pengukuhan Jabatan Guru Besar dalam Bidang Ilmu Sastra di Fakultas Sastra Universitas Udayana Denpasar, 1 Mei 2004.

Suseno, Franz Magnis. 1993. Etika Jawa:Sebuah Analisa Falsasi Tentang Kebijakan Hidup Jawa. Jakarta: Gramedia Pustaka Utama.

Teeuw, A. 1988. Sastra dan Ilmu Sastra: Pengantar Teori Sastra. Jakarta: Pustaka Jaya. 